\title{
薄板のスティフナ形態の最大剛性設計法 ${ }^{*}$ \\ （第 1 報，連続構造モデルによる取り扱い）
}

\author{
山崎 光 说*1, 小林篤 司*2
}

Optimum Compliance Design of Stiffner Layout of Thin Plate

(1st Report, A Treatment as Pseudo-continuous Structure)

Kouetsu YAMAZAKI and Atsushi KOBAYASHI

\begin{abstract}
An optimum design technique of the stiffner layout which gives minimum compliance is developed. A thin plate with stiffners is treated as an anisotropic plate of pseudo-continuous structure, and is discretized into the finite elements. The minimum compliance design subjected to the constant volume, in which the distributions of angles of the stiffner arrangement and the stiffner densities are varied, is determined by the recursive quadratic programming technique.

By applying this design technique, the optimum layouts of the stiffner of the rectangular plate under some typical loading and supporting conditions are obtained.
\end{abstract}

Key Words : Design Engineering, Minimum Compliance Design, Optimum Layout of Stiffner, Pseudo-continuous Structure, Recursive Quadratic Programming, Finite Element Method.

\section{1.はじぬに}

平板や殸椛造物にスティフナ（補強リブとも呼ぶ） を付けた構造形態が補強あるいは軽量化の観点から実 際の設計に採用されることが多い.したがって，その ようなスティフナ構造物の強度的最適設計法に関する 研究も実用上重要な課題であるが, 従来の研究の大半 はあらかじめ規定したスティフナ配置形態の下での各 スティフナの寸法や配置間隔の最適化を目的としたも のが多い(1)，(2)，一方，スティフナの配置形態そのも のを諭じた研究としては，無限小板厚のスティフナを 1 方向に無数に配犆した擬似連続体構造（Integral stiffner）の概念によって円板の円周方向配置スティ フナの理論的極限取り扱ったChengよ Olhoffの一 連の研究 ${ }^{(3)}{ }^{(4)}$ が見られるのみで，一般的なスティフ ナ形態について諭じられたことはない。

そこで本研究では，任意の負荷条件，支持条件のも とでの理諭的極限構造としてのスティフナ最適形態を

* 昭和 62 年 11 月 21 日 第 949 回講演会において講演, 原稿 受付 昭和 62 年 4 月 27 日.

*1 正員, 金沢大学工学部 (严920 金沢市小立野 2-40-20)。

*2 准員, 鈴木自動車工業(株)（《432-91 静岡県浜名郡可美村 高塚 300).
諭ずることを目的として，Chengよ Olhoff のスティ フナ擬似連続体の概念を二方向スティフナ・モデルに 拡張し, 有限要素法と数理計画法を用いた最大剛性設 計手法を提案する。ささらに本手法を基本的な負荷・支 持条件下の正方形板等に適用し，その最適スティフナ 形態について論ずる。

\section{2. 迎続㮐造モデルとその最大泪性設計間題}

2 ・1 スティフナ梅造の逗続体モデル本研究 では，まずスティフナの最適配置形態が究極的には直 交曲線網で与えられると仮定し, 直交曲線に沿ってス ティフナが連続的に分布する極限棈造を対象とする. このとき，このスティフナが連続的に分布するモデル は一種の直交異方性板と見なすことができる。

図 1 に示すように板の中央面内に $(x, y)$ ，たわみ方 向に $z$ 軸をとり，スティフナに沿った直交曲線網の接 線方向を $(\alpha, \beta)$ として， $\alpha$ 方向亡 $x$ 軸之の成す角を $\varphi$ とする。たわみを $w$ として，板の部分での応力 $\left(\sigma_{\alpha \alpha}^{p}\right.$, $\left.\sigma_{\beta \beta}^{p}, \sigma_{\alpha \beta}^{p}\right)$ とたわみの関係は薄板の曲げ理論より次式 で与えられる。

$$
\sigma_{\alpha \alpha}^{p}=-\frac{E z}{1-\nu^{2}}\left(w_{1, \alpha a}+\nu w_{, \beta \beta}\right),
$$




$$
\begin{aligned}
& \sigma_{\beta \beta}^{p}=-\frac{E z}{1-\nu^{2}}\left(\nu w_{, \alpha \alpha}+w_{, \beta \beta}\right), \\
& \sigma_{\alpha \beta}^{p}=-\frac{E z}{1-\nu^{2}} w_{, \alpha \beta} \cdot \cdots \cdots
\end{aligned}
$$

ここにE，レは板材のヤング率，ポアソン比を表し， また

$$
w_{, \alpha \alpha}=\frac{\partial^{2} w}{\partial \alpha^{2}}, \quad w_{, \alpha \beta}=\frac{\partial^{2} w}{\partial \alpha \partial \beta}, \quad w_{, \beta \beta}=\frac{\partial^{2} w}{\partial \beta^{2}} \cdots
$$

とする。一方, スティフナ部での応力 $\left(\sigma_{\alpha \alpha}^{s}, \sigma_{\beta \beta}^{s}, \sigma_{\alpha \beta}^{s}\right)$ とたわみの関係は，スティフナが交差することによっ て発生するせん断変形抵抗を無視して,

$$
\sigma_{\alpha \alpha}^{s}=-E z w_{, \alpha \alpha}, \quad \sigma_{\beta \beta}^{s}=-E z w_{, \beta \beta}, \quad \sigma_{\alpha \beta}^{s}=0 . \cdots
$$

そこで，図2のようにスティフナ部の詳細をモデル 化する. $\Delta C_{\alpha}$ 年間の $\alpha$ 方向スティフナの幅の合計， $h_{\alpha}, h_{\beta}$ をそれぞれ $\alpha, \beta$ 方向のスティフナ高さ， $h_{0}$ を平 板の板厚とするとモーメントの釣合い式より

$$
\Delta \beta M_{\alpha \alpha}=-2 \Delta \beta \int_{0}^{\frac{h_{0}}{2}} \sigma_{\alpha \alpha}^{p} z \mathrm{~d} z-2 \Delta C_{\alpha} \int_{\frac{10}{2}}^{\frac{h_{\alpha}}{2}} \sigma_{\alpha \alpha}^{s} z \mathrm{~d} z \cdot \cdots(4)
$$

上式に式 (1)，(3)を代入するとモーメント $M_{a \alpha}$ とたわ みの関係式が次式で与えられる。

$$
\begin{aligned}
M_{\alpha \alpha}= & -D_{0}\left(1+\left(1-\nu^{2}\right)\left\{\left(\frac{h_{\alpha}}{h_{0}}\right)^{3}-1\right\} b_{\alpha}\right) w_{. \alpha \alpha} \\
& -D_{0} \nu w_{, \beta \beta} \ldots \ldots \ldots \ldots \ldots \ldots \ldots \ldots \ldots \ldots \ldots
\end{aligned}
$$

ただし， $D_{0}=E h_{0}^{3} / 12\left(1-\nu^{2}\right)$ とする。また $M_{\beta \beta}, N_{\alpha \beta}$ あ 同様にして次式で定義される。

$$
\begin{aligned}
M_{\beta \beta}= & -D_{0} \nu w_{, \alpha \alpha}-D_{0}\left(1+\left(1-\nu^{2}\right)\right. \\
& \left.\times\left\{\left(\frac{h_{\beta}}{h_{0}}\right)^{3}-1\right) b_{\beta}\right) w_{, \beta \beta}, \\
M_{\alpha \beta}= & -D_{0}(1-\nu) w_{, \alpha \beta} \cdots \cdots
\end{aligned}
$$

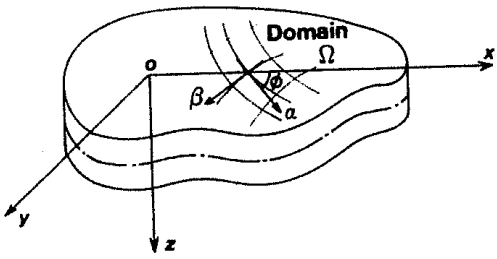

図1連続スティフナ構造そデル

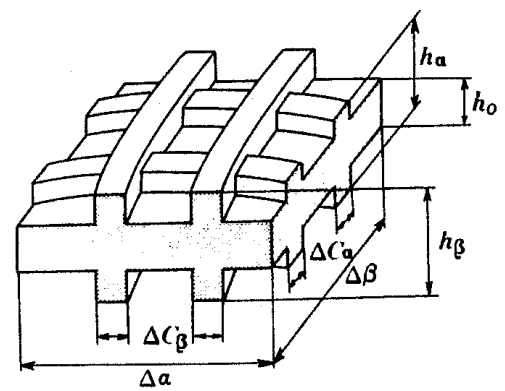

図 2 連続スティフナ構造詳細
ただし， $b_{\alpha}, b_{\beta}$ は幅方向密度亡呼び，次式で定義する。

$$
b_{\alpha}=\Delta C_{\alpha} / \Delta \beta, \quad b_{\beta}=\Delta C_{\beta} / \Delta \alpha .
$$

式 (5)，(6)，(7) より連続スティフナモデルは, 次の ような応力ーひずみ関係を持つ板厚 $h_{0}$ の一種の直交異 方性板として取り扱うことができる。

$$
\begin{aligned}
\sigma_{\alpha \alpha} & =\frac{E\left\{1+\left(1-\nu^{2}\right) \rho_{\alpha}\right\}}{1-\nu^{2}} \varepsilon_{\alpha \alpha}+\frac{E \nu}{1-\nu^{2}} \varepsilon_{\beta \beta}, \\
\sigma_{\beta \beta} & =\frac{E \nu}{1-\nu^{2}} \varepsilon_{\alpha \alpha}+\frac{E\left\{1+\left(1-\nu^{2}\right) \rho_{\beta}\right\}}{1-\nu^{2}} \varepsilon_{\beta \beta}, \\
\sigma_{\alpha \beta} & =\frac{E}{2(1+\nu)} \varepsilon_{\alpha \beta} \ldots \ldots \ldots \ldots \ldots
\end{aligned}
$$

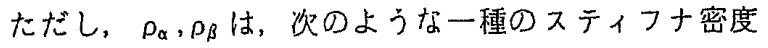
を表す。

$$
\rho_{\alpha}=\left\{\left(\frac{h_{\alpha}}{h_{0}}\right)^{3}-1\right\} b_{\alpha}, \quad \rho_{\beta}=\left\{\left(\frac{h_{\beta}}{h_{0}}\right)^{3}-1\right\} b_{\beta} \cdot(10)
$$

2 - 2 最大测性没訓间题 前節で定めたスティフ ナ・モデルのスティフナ密度 $\rho_{\alpha}, \rho_{\beta}$ とスティフナ配向 角 $\varphi （ \alpha$ 軸之 $x$ 軸のなす角）を設計変数にとり, 目的 関数 $f$ として次式で示吉外力仕事を選ぶ.

$$
\begin{gathered}
f\left(\varphi, \rho_{\alpha}, \rho_{\beta}\right)=\frac{1}{2} \iint_{\Omega} p w d x d y \rightarrow \min \cdots \cdots \\
\rho_{\alpha}, \rho_{\beta} \geqq 0 .
\end{gathered}
$$

ただし， $p$ は分布荷重，積分は解析対象領域 にに関す る領域積分よする。式（11）はひずみエネルギを最小 にすること亡等価であり，領域 $\Omega$ 全域の平均的な剛性 を最大にすることを意味する。なお，たわみw仗式 の全ポテンシャル・エネルギを停留する解でなければ ならない.

$$
\begin{aligned}
\pi= & \frac{D_{0}}{2} \iint_{\Omega}\left[\left\{1+\left(1-\nu^{2}\right) \rho_{\alpha}\right\} w_{, \alpha \alpha}^{2}+2 \nu w_{, \alpha \alpha} w_{, \beta \beta}\right. \\
& \left.+\left\{1+\left(1-\nu^{2}\right) p_{\beta}\right\} w_{, \beta \beta}^{2}+2(1-\nu) w_{, \alpha \beta}^{2}\right] \mathrm{d} x \mathrm{~d} y \\
& -\iint_{\Omega} p w \mathrm{~d} x \mathrm{~d} y . \cdots \ldots \ldots \ldots \ldots \ldots \ldots \ldots
\end{aligned}
$$

一方、制約条件として配置するスティフナの全体 積一定の条件を課する。すなわち，

$$
\begin{aligned}
g & =\iint_{\Omega}\left(h_{0}+\left(h_{\alpha}-h_{0}\right) b_{\alpha}+\left(h_{\beta}-h_{0}\right) b_{\beta}\right. \\
& \left.-\left\{\min \left(h_{\alpha}, h_{\beta}\right)-h_{0}\right\} b_{\alpha} b_{\beta}\right] \operatorname{d\alpha d} \beta-V_{0} \leqq 0 \cdots
\end{aligned}
$$

ここに， $V_{0}$ は，あらかじめ規定するモデル全体の体 積とする。

\section{3，有限㱠菜モデルとその最適化}

3. 1 有限要素への蜼敌化直交曲線網に沿 ってスティフナが配向されたモデルを 8 節点二次の アイソパラメトリック要素を用いて離散化する(5), (6) 要素内の任意の点のスティフナの配向角 
ティフナ密度 $\rho_{\alpha}, \rho_{\beta}$ を 4 隄節点の値 $\varphi_{i}, \rho_{\alpha i}, \rho_{\beta i}$ と一次 の内择関数 $R_{i}(i=1,2,3,4)$ を用いて次のように表す。

$$
\varphi=\sum_{i} R_{i} \varphi_{i}, \rho_{\alpha}=\sum_{i} R_{i} \rho_{\alpha i}, \rho_{\beta}=\sum_{i} R_{i} \rho_{\beta i} . \cdots(14)
$$

ただし，板中央面内にとった要素正規座標を $(\xi, \eta)$ ， 4 隅点の座標を $\left(\xi_{i}, \eta_{i}\right)$ として,

$$
R_{i}(\xi, \eta)=\frac{1}{4}\left(1+\xi_{i} \xi\right)\left(1+\eta_{i} \eta\right) .
$$

一方，節点変位ベクトルを $(\delta)_{i}^{\top}=\left(w_{i}, \theta_{x i}, \theta_{y i}\right)$

( $\theta_{x i}, \theta_{y i}$ は $x, y$ 卌まわりの回転角) 亡すると，二次 の内插関数 $N_{i}$ を用いて要素内の変位 $u, v, w$ を次式で表 す.

$$
\begin{array}{r}
u=-\sum_{i} N_{i} \zeta \frac{h_{0}}{2} \theta_{y i}, v=\sum_{i} N_{i} \zeta \frac{h_{0}}{2} \theta_{x i}, w=\sum_{i} N_{i} w_{i} . \\
\ldots \ldots \ldots \ldots \ldots \ldots \ldots
\end{array}
$$

ただしらは板の上下面でェ1となる正規座標とする。

このとき姴素内のひずみ $\{\varepsilon\}^{\mathrm{T}}=\left(\varepsilon_{x}, \varepsilon_{y}, \gamma_{x y}\right)$ は通常の 定義により，ひずみ一変位マトリックス $[B]$ を用い て次のように表せる。

$$
\{\varepsilon\}=[B]\{\delta\} ;\{\delta\}^{\top}=\left(\delta_{1}, \cdots, \delta_{8}\right) \cdots
$$

ひずみの座標変換によりスティフナ配置方向のひずみ $\{\hat{\varepsilon}\}^{\top}=\left(\varepsilon_{\alpha \alpha}, \varepsilon_{\beta \beta}, \varepsilon_{\alpha \beta}\right)$ は

$$
\{\hat{\varepsilon}\}=[T][B]\{\delta\} \ldots \ldots \cdots \cdots(18)
$$

ここに $[T]$ はひずみの座標変換マトリックスとする.

$$
[T]=\left[\begin{array}{ccc}
c^{2} & s^{2} & c s \\
s^{2} & c^{2} & -c s \\
-c s & c s & c^{2}-s^{2}
\end{array}\right], \quad \begin{aligned}
& c=\cos \varphi, \\
& s=\sin \varphi . \\
& \ldots \ldots \ldots
\end{aligned}
$$

また式(9)より，応カーひずみマトリックスを $[D]$ 之すると，スティフナ配置方向の応力 $\{\hat{\sigma}\}^{\top}=\left(\sigma_{\alpha a}, \sigma_{\beta \beta}\right.$, $\left.\sigma_{\alpha \beta}\right)$,

$$
\{\hat{\sigma}\}=[D][T][B]\{\delta\} \ldots \ldots \ldots(20)
$$

したがって本研究で取り扱う擬似連続体の要翡㴊性、 トリックス $[K]^{e}$ は次式で評洒す机ばよいことになる。

$$
\begin{aligned}
{[K]^{e}=} & \int_{-1}^{1} \int_{-1}^{1} \int_{-1}^{1}[B]^{\top}[T]^{\top}[D][T][B] \\
& \times|J| \mathrm{d} \xi \mathrm{d} \eta \mathrm{d} \zeta \ldots \ldots \ldots \ldots(21)
\end{aligned}
$$

$3 \cdot 2$ 曼適化之感度解析 具体的な設計変数之

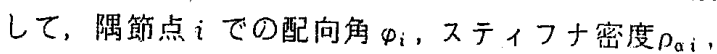
郘iをとる。また最適化の手法としてPshenichnyの 線形化法 (PLM法) $)^{(7)}$ を用いる。 この手法怯遂次二次計 画法の一種で，設計点近傍で目的関数を二次近似，制 約条件を一次近似し，その停留条件より設計变数の修
正ベクトルを求める逐次解法である。またこの手法の 特徽柱, 目的関数および例約条件の一階微係数（設計 感度）のみを用いて二次の収束性が保証される点にあ る。以下ではそれらの設計感度解析法について示す。

3. 2. 1 目刉阅数の設部感度 式 (12)の全ポテ ンシャル・エネルギォを停留させるたわみいがなす外 力仕事は弾性ひずみエネルギに等しく，したがって式 (11) の目的関数 $f$ の設計感度は解析領域 $\Omega$ Ф形状が 変化しない場合，Dens よMrözによ机ば $\pi の$ 第 1 変分 と等洒である。すなわち，設計変数を一般的に $x\left(\varphi_{i}\right.$ ， $\left.\rho_{\alpha i}, \rho_{\beta i}\right)$ ，応力ーひずみ関係を $\sigma=D \varepsilon て ゙$ 表すと,

$$
\delta f=-\frac{1}{2} \int_{\Omega} \varepsilon^{\top} \frac{\partial D}{\partial x} \varepsilon \delta x d \Omega . \cdots \ldots \ldots \ldots
$$

具体的な設計翂数を用いると応力ーひずみマトリッ クスは $D\left(\varphi, \rho_{\alpha}, \rho_{\beta}\right)$ と考えることができ，したがって 式 (22) より隅節点 $i$ での設計変数を $\varphi_{i}, p_{\alpha i}, \rho_{\beta i}$ 亡す れば,

$$
\begin{aligned}
\delta f= & -\frac{1}{2} \iint_{\Omega}\left(\{ \hat { \varepsilon } \} ^ { \top } \left(\frac{\partial[T]^{\top}}{\partial \varphi_{i}}[D][T]\right.\right. \\
& \left.+[T]^{\top}[D] \frac{\partial[T]}{\partial \varphi_{i}}\right)(\hat{\varepsilon}) \delta \varphi_{i} \\
& -\{\hat{\varepsilon}\}^{\top}[T]^{\top} \frac{\partial[D]}{\partial \rho_{\alpha i}}[T]\{\hat{\varepsilon}\} \delta \rho_{\alpha i} \\
& \left.-\{\hat{\varepsilon}\}^{\top}[T]^{\top} \frac{\partial[D]}{\partial \rho_{\beta i}}[T]\{\hat{\varepsilon}\} \delta \rho_{\beta i}\right] \mathrm{d} x \mathrm{~d} y
\end{aligned}
$$

ただし

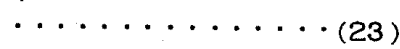

$$
\begin{aligned}
& \frac{[D]}{\partial \rho_{\alpha i}}=E R_{i}\left[\begin{array}{lll}
1 & 0 & 0 \\
0 & 0 & 0 \\
0 & 0 & 0
\end{array}\right], \quad \frac{[D]}{\partial \rho_{\beta i}}=E R_{i}\left[\begin{array}{lll}
0 & 0 & 0 \\
0 & 1 & 0 \\
0 & 0 & 0
\end{array}\right], \\
& \frac{[T]}{\partial \varphi_{i}}=\frac{[T]}{\partial \varphi} R_{i} \ldots \ldots \ldots \ldots \ldots \ldots \ldots
\end{aligned}
$$

3. 2.2 制約条俳の設計感度 次に制約条件の 設計感度を求める. 設計変数 $\rho_{\alpha i}, \rho_{\beta i}$ の具体的な変量 としてりブ丈 $h_{\alpha}, h_{\beta}$ あるいは愊密度 $b_{\alpha}, b_{\beta}$ のいずれか をとるものとする。.まず $h_{\alpha}=h_{\beta}=h$ （一定）とした場合， 体積一定の制約条件式 (13) は正規座標に変換した次 式で評価できる。

$$
\begin{aligned}
g= & h_{0} \sum_{e} \int_{-1}^{1} \int_{-1}^{1}\left\{1+\frac{h_{0}^{2}}{h^{2}+h h_{0}+h_{0}^{2}}\left(\rho_{a}+\rho_{\beta}-\frac{h_{0}^{3}}{h^{3}-h_{0}^{3}} \rho_{\alpha} \rho_{\beta}\right)\right\} \\
& \times|J| \mathrm{d} \xi \mathrm{d} \eta-V_{0} \leqq 0 . \cdots \cdots \cdots \cdots \cdots \cdots(25)
\end{aligned}
$$

総和は全要素に関する和を意味する。したがって式 (14)を用いて上式より制約条件の設計感度は次式亡な る.

$$
\begin{aligned}
\frac{\partial g}{\partial \rho_{a i}}= & \frac{h_{j}^{3}}{h^{2}+h h_{0}+h_{i j}} \sum_{e} \int_{-1}^{1} \int_{-1}^{1} R_{i}\left(1-\frac{h_{0}^{3}}{h^{3}-h_{0}^{3}} \sum_{j} R_{j} \rho_{\beta j}\right) \\
& \times|J| \mathrm{d} \xi \mathrm{d} \eta .
\end{aligned}
$$




$$
\begin{aligned}
\frac{\partial g}{\partial \rho_{\beta i}}= & \frac{h_{0}^{3}}{h^{2}+h h_{0}+h_{0}^{2}} \sum \int_{e}^{1} \int_{-1}^{1} R_{i}\left(1-\frac{h_{0}^{3}}{h^{3}-h_{0}^{3}} \sum_{j} R_{j} p_{\alpha j}\right) \\
& \times|J| \mathrm{d} \xi \mathrm{d} \eta \ldots \ldots \ldots \ldots \ldots \ldots \ldots \ldots \ldots(26)
\end{aligned}
$$

なお $\partial g / \partial \varphi_{i}=0$.

一方， $b_{\alpha}=b_{\beta}=b$ (一定) としたときの体租制約条件 は式（13）を正規座標に変換して次式で評価できる。

$$
\begin{aligned}
g= & h_{0} \sum_{e} \int_{-1}^{1} \int_{-1}^{1}\left\{(1-b)^{2}+\left(\sqrt[3]{\frac{\rho_{a}}{b}+1}+\sqrt[3]{\frac{\rho_{\beta}}{b}+1}\right) b\right. \\
& \left.-\sqrt[3]{\frac{\min \left(\rho_{\alpha}, \rho_{\beta}\right)}{b}+1} b^{2}\right\}|J| \mathrm{d} \xi \mathrm{d} \eta . \cdots
\end{aligned}
$$

したがって,このときの設計感度は $\rho_{\alpha} \geqq \rho_{\beta}$ の領域で は,

$$
\begin{aligned}
\frac{\partial g}{\partial \rho_{\alpha i}}= & \frac{h_{0}}{3} \sum_{e} \int_{-1}^{l} \int_{-1}^{1} R_{i}\left(\frac{1}{b} \sum_{j} R_{j} \rho_{\alpha j}+1\right)^{-\frac{2}{3}}|J| \mathrm{d} \xi \mathrm{d} \eta, \\
\frac{\partial q}{\partial \rho_{\beta i}}= & \frac{h_{0}(1-b)}{3} \sum_{e} \int_{-1}^{1} \int_{-1}^{1} R_{i}\left(\frac{1}{b} \sum_{j} R_{j} \rho_{\beta j}+1\right)^{-\frac{2}{3}} \\
& \times|J| \mathrm{d} \xi \mathrm{d} \eta \ldots \ldots \ldots \ldots \ldots
\end{aligned}
$$

また $\rho_{\alpha}<p_{\beta}$ の領域では次式で評洒できる。

$$
\begin{aligned}
\frac{\partial g}{\partial \rho_{\alpha i}}= & \frac{h_{0}(1-b)}{3} \sum_{e} \int_{-1}^{l} \int_{-1}^{l} R_{i}\left(\frac{1}{b} \sum_{j} R_{j} \rho_{a j}+1\right)^{-\frac{2}{3}} \\
& \times|J| \mathrm{d} \xi \mathrm{d} \eta \\
\frac{\partial g}{\partial \rho_{\beta i}}= & \frac{h_{0}}{3} \sum_{e} \int_{-1}^{l} \int_{-1}^{l} R_{i}\left(\frac{1}{b} \sum_{j} R_{j} \rho_{\beta \alpha j}+1\right)^{-\frac{2}{3}} \\
& \times|J| \mathrm{d} \xi \mathrm{d} \eta \ldots \ldots \ldots \ldots \ldots \ldots
\end{aligned}
$$

\section{4. 設計例}

4 - 1 対辺的納支持平板 図 3 に示すような両端 を単純支持した $a=2 b, h_{0} / a=1 / 32$ の長方形板に等分布

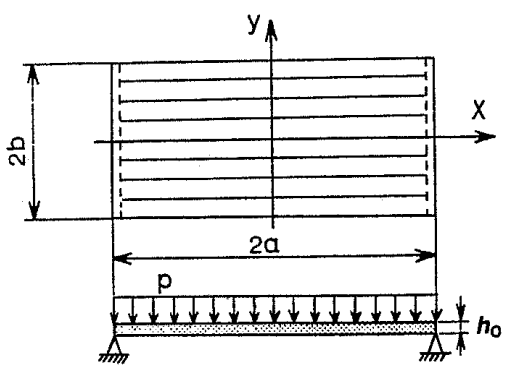

図 3 対辺単純支持平板解析モデル

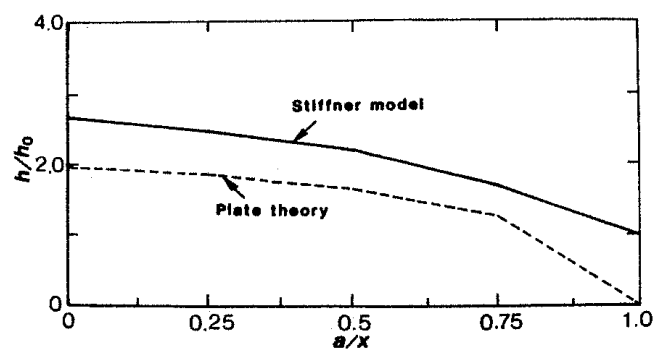

図 4 スティフナの最適形状
荷重 $\mathrm{p}$ が作用するモデルを考える。このモデルはステ ィフナを $x$ 軸に平行に一方向だけ配置すれば十分だと

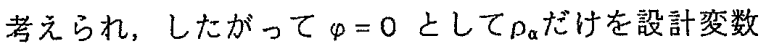
に選んだ，さらに簡単化のため， $b_{\alpha}=1 / 2, b_{\beta}=0$ に固定 し，体積を $\gamma=1.5 a b h_{0}$ に規定した。つまり式（10）の $\rho_{\alpha}, \rho_{\beta}$ は次式となる。

$$
\rho_{\alpha}=\frac{1}{2}\left\{\left(\frac{h_{\alpha}}{h_{0}}\right)^{3}-1\right\}, \rho_{\beta}=0 .
$$

これよりこの問題はスティフナ高さを変化させる設 計問題となる. 高さ $h_{\alpha}$ の初期值としてスティフナ部分 も等洒体積の板と考えたときの最大㴊性設計の解を用 いた。

図 4 にスティフナの最適形状を, 全体を一つの板と 考えたときの板理論による変厚板の最適形状と比較し て示す. また表 1 は最適形状での目的関数を比較して 示したものである。ここで $f_{0}$ とは等体積の一様板厚モ デル（等洒板厚モデル） $h_{\mathrm{eq}}=1.5 h_{0}$ の外力仕事であり， スティフナ高さが板厚と等しいha一定モデル, モデル 全体を一つの変厚板と見なした板理論および本手法に よる最適モデルのそれぞれの值を $f_{0}$ との比で示してあ る。同表から明らかなように本手法による最適モデル は等伍板厚モデルに比べて $80.0 \%$ ，変厚板モデルに比 ベて $15.8 \%$ 㧩性が向上していることが了解される.

$4 \cdot 2$ 全周篮純支持平板 全周が単純支持され た板厚 $h_{0}$, 一辺 $2 a\left(h_{0} / a=0.01\right)$ の正方形板に等分布 荷重 $p$ が作用するモデルを考える。モデルの対称性か

表 1 目的関数值の比較

\begin{tabular}{|c|c|}
\hline Model & $\begin{array}{c}\text { Objective } f / f_{0} \\
\text { function }\end{array}$ \\
\hline $\begin{array}{c}\text { Plate with constant } \\
\text { height stiffner }\end{array}$ & 0.8542 \\
\hline $\begin{array}{c}\text { Variable thickness } \\
\text { plate }\end{array}$ & 0.6436 \\
\hline $\begin{array}{c}\text { Plate with variable } \\
\text { height stiffner }\end{array}$ & 0.5556 \\
\hline
\end{tabular}

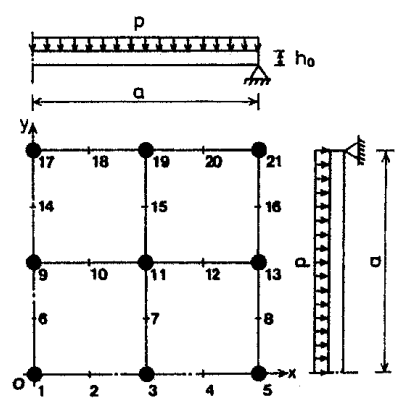

図 5 全周単純支持平板解析モデル 


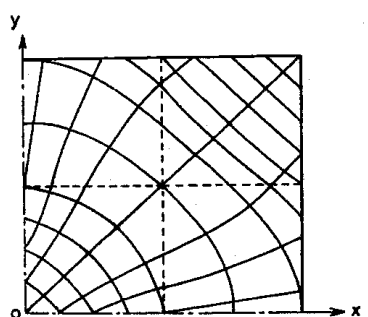

(a) 解析結果

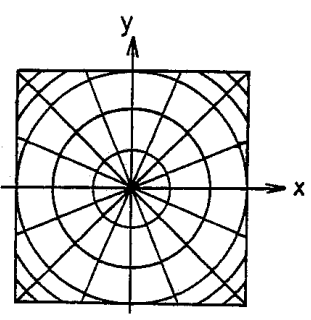

(b) 模式図
図 6 最適スティフナ形態

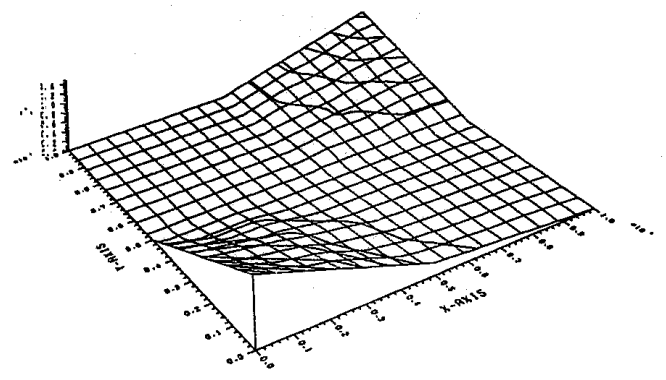

(a) $\rho_{\alpha}$ 分布

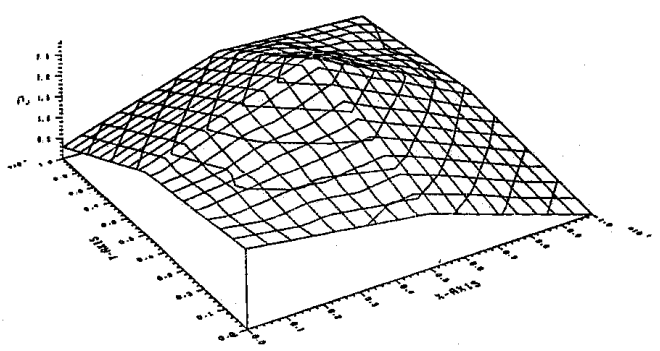

(b) $\rho_{\beta}$ 分布

図 7 スティフナ密度分布

ら図 5 に示すように1/4領域を要素分割し，各隅節点 $\circlearrowleft \varphi_{i}, \rho_{\alpha i}, \rho_{\beta i}$ を設計変数にとり最適化を行った. 本例 題では， $h_{\alpha}=h_{\beta}=2 h_{0}, V_{0}=1.19 a^{2} h_{0}$ 亡規定し, 初期値 よして全隅節点で $\varphi_{i}=0, \rho_{\alpha i}=\rho_{\beta i}=0.7$ を与えた。

113 回の繰返しの後, $f / f_{0}=1.27 \rightarrow 0.811$ まで減少 し，初期設計と比べて $56.7 \%$ 刷性が向上した。表 2 は 最適解にお忊可設計変数の值を，また図 6 はスティフ ナの最適配置形態を示している。同図 (a) 仙設計変数 $\varphi_{i}$ の値を用い, $\mathrm{d} y / \mathrm{d} x=\tan \varphi$ より得られる次式の常微 分方程式をハミング法で解き描いたものである。

$$
\frac{\mathrm{d} \xi}{\mathrm{d} \eta}=-\frac{\sum_{i} \frac{\partial R_{i}}{\partial \xi}\left(y_{i}-x_{i} \tan \varphi\right)}{\sum_{i} \frac{\partial R_{i}}{\partial \eta}\left(y_{i}-x_{i} \tan \varphi\right)} \cdot \cdots \cdots
$$

つまりスティフナの最適形態は板中心から放射状に伸 びるスティフナとこれと直交する円周方向スティフナ
表 2 最適解に求ける設計変数値

\begin{tabular}{|c|c|c|c|}
\hline Nodal No. & $2 \varphi_{i} / \pi$ & $\rho_{\alpha i}$ & $\rho_{\beta i}$ \\
\hline 1 & 0.506 & 1.299 & 1.578 \\
\hline 3 & 0.212 & 1.969 & 1.126 \\
\hline 5 & 0.106 & 0.000 & 0.000 \\
\hline 9 & 0.789 & 0.000 & 1.371 \\
\hline 11 & 0.528 & 0.000 & 2.890 \\
\hline 13 & 0.592 & 0.000 & 1.277 \\
\hline 17 & 0.897 & 0.000 & 0.279 \\
\hline 19 & 0.440 & 0.000 & 1.656 \\
\hline 21 & 0.491 & 0.879 & 1.662 \\
\hline
\end{tabular}

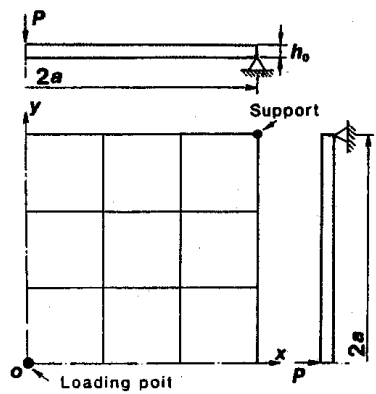

図 8，4 隅支持平板解析モデル

表 3 最適解への収束過程

\begin{tabular}{|c|c|c|}
\hline $\begin{array}{c}\text { Iteration } \\
\text { No: }\end{array}$ & $\begin{array}{c}\text { Objective } f / f_{0} \\
\text { function }\end{array}$ & $\begin{array}{c}\text { Volume } \\
V / V_{0}\end{array}$ \\
\hline 0 & 0.6628 & 1.0000 \\
\hline 100 & 0.6624 & 0.9997 \\
\hline 200 & 0.5917 & 0.9998 \\
\hline 270 & 0.5696 & 0.9995 \\
\hline 275 & 0.5670 & 1.0000 \\
\hline
\end{tabular}

で構成されている．図6 (b) は同図 (a)を元に対称性 を考慮し，最終形態の予测を模式的に示したものであ る。一方, 設計变数 $\rho_{\alpha}, \rho_{\beta}$ のスティフナ密度分布を図 7 に示す。同図より $\rho_{\alpha}$ は中心部之 4 隅部で密度分布が 高く, 密度 $p_{\beta}$ は $1 / 4$ 領域の中央部が高い分布を示して いる。

4-34 晴点支持平板支持条件, 負荷条件の 異な百例題として図 8 に示すように 4 隅を点支持した 一辺 $2 a$ の正方形板の中心に集中荷重 $P$ が作用するモ デルを考える，板厚 $h_{0} / a=0.018$ とし， $V_{0}=3.72 a^{2} h_{0}$ ， スティフナ密度 $b_{\alpha}=b_{\beta}=0.0412$ 之規定した。 初期值は 全隅節点で $h_{\alpha}=h_{\beta}=4 h_{0}$ 亡仮定した.

表 3 に最適解への収束過程を示す，繰返しを 275 回 行い, $f / f_{0}=0.663 \rightarrow 0.567$ まで减少した。このモデ ルでは初期設計の段階で既に等価板厚モデルの約 1.5 倍の凬性を持つが，これはスティフナ高さを板厚の3 

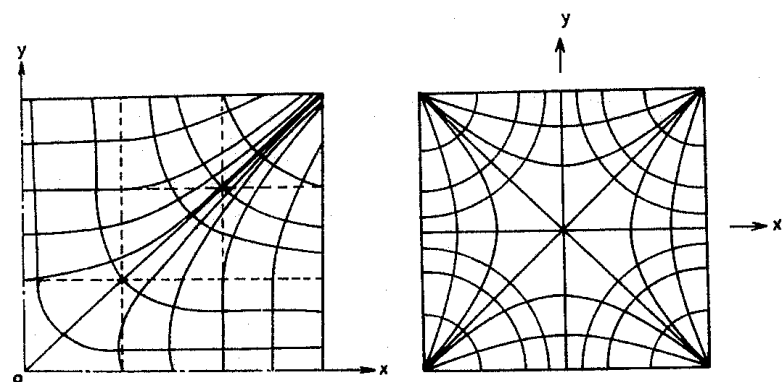

(a) 解析結果 (b) 模式図

図 9 最適スティフナ形態

倍に設定したためでここれよりスティフナ高さの方が 密度 $b_{\alpha}$ ，郘よりも嗍性の向上に対する寄与が大きいこ とがわかる。また最適解での剛性は等伍板厚モデルに 比べて76.4\%向上した. スティフナの最邀形態を前例 之同様にして描いたものを図 9 (a)に示す，同図より

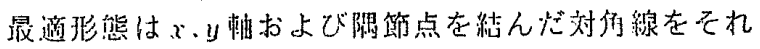
ぞれ濑近線亡ずる直交双曲線網と類似の分布を示して いる. 図 9(b)はこれを模式的に示したものである. さらに図10はスティフナ高さの分布を示したもので， $h_{\alpha}$ は1 $/ 4$ 領域の中央部が低く， $h_{\beta}$ は $h_{\alpha}$ の低い所を補う ように分布している。

\section{5. 結言}

本研究ではスティフナで補強された薄板構造を，直 交曲線網に沿ってスティフナが連続的に分布する理想 的な極限構造モデルと見なして，応力ーひずみ関係な よ゙の定式化, 有限要素への離散化を行い, さらに体積 制約下の最大剛性設計問題への定式化を行った. 最適 化のための数理計画法としてPLM法を用い，2，3の 例題によりその有効性を確認すると共に，各支持条件・ 負荷条件に対応した特徽あるスティフナ配置形態を得 た。

最後に本研究は文部省科学研究費補助金（奨励研究 A)によるものであることを付記する。

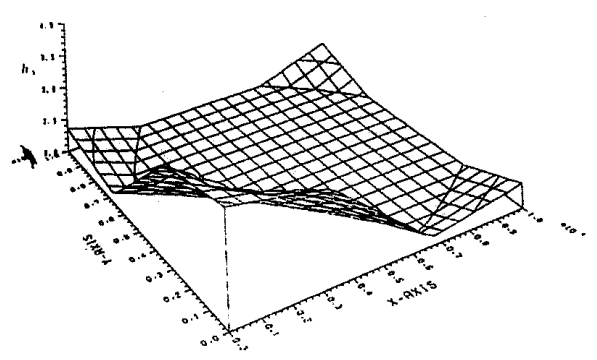

(a) $h_{a}$ 分布

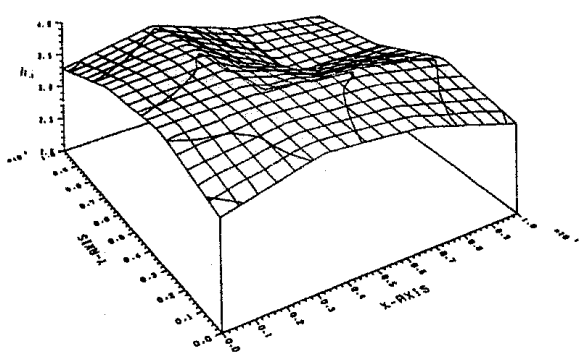

(b) $h_{\beta}$ 分布

図10 スティフナ高さ分布

文嗝

(1) Patnaik, S.N. and Sankaran, G.V., Int. J. Num. Methods Engng., 10-2(1976), 283.

(2) Richards, D.M. , Int. J. Solids \& Struct., 12-11(1976),791.

(3) Cheng, K.T., Int. J. Solids \& Struct. , 17-8 (1981), 795 .

(4) Cheng, K.T. and Olhoff, N., Int. J. Solids \& Struct.,18-2(1982),153.

(5) Zienkiewicz, O.C., ほか 2 名, Int. J. Num. Methods Engng., 3(1971),275.

(6) Zienkiewicz, O.C. and Bruce, M.I., Int. J. Num. Methods Engng., 2(1970), 419.

(7) Choi, K.K. 、泳か3名. Trans. ASME, 105-1(19 $83), 91$.

(8) Dens, K. and Mröz, Z., Int. J. Solids \& Struct. , 19-8(1983),679. 


\section{討論}

(質問〕多田幸 生〔神戸大学工学部】

（1）式(22)において， $\pi$ の第 1 変分を求めるとき, 設計変数の影響として，応力ーひずみマトリックスの 変分のみを考えているようであるが, 設計変数の変化 による応力, あるいはひずみの陰な変化の項,すなわ ち, $\partial \varepsilon / \partial x$ は考えなくてよいのか.

（2）例題の結果（図 6 おび図 9) は非常に興味 深いが,これらの最適スティフナ形態の違いを, 力学 的にはどのように解釈すればよいのか.

〔回答〕（1）式(22)は式(11)上り得られる目的 関数 $f$ の第 1 変分

$$
\delta f=\frac{1}{2} \int_{\Omega} p \delta w d \Omega
$$

に対して設計変数が応力ーひずみマトリックスのみに

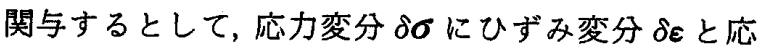
カーひずみマトリックス変分 $\delta \boldsymbol{D}(\delta \sigma=\boldsymbol{D} \delta \varepsilon+\delta \boldsymbol{D} \varepsilon)$ を 考慮し，仮想仕事の原理などを用いて導出されたもの で厳密な表現である.詳細は文献 (8)を参照されたい. （2）一様分布負荷，周辺単純支持の場合には図 6 のように平板中心から放射状にのびるスティフナおよ び同心円状スティフナで構成されている。一方, 中央 集中負荷，4 隅点支持の場合には図 9 のように支持点 に集中する双曲線状のスティフナ形態となっており, これらの相違は負荷条件および支持条件の違いによっ て生じているものと解釈できる. 